\author{
Wojciech Koman \\ https://orcid.org/0000-0002-6000-7664 \\ Uniwersytet Śląski w Katowicach \\ Wydział Nauk Przyrodniczych, Sosnowiec \\ Instytut Geografii Społeczno-Ekonomicznej i Gospodarki Przestrzennej \\ wojciech.koman@outlook.com
}

\title{
PODZIEMNA PRZESTRZEŃ KULTURALNA ZABRZA W KOPALNI „GUIDO”
}

\begin{abstract}
Abstrakt: Współczesny rozwój miast to efekt oddziaływania wielu czynników, które w mniejszym lub większym stopniu wynikają z polityki prowadzonej przez władze samorządowe. Wśród uwarunkowań rozwoju lokalnego szczególną rolę pełni kultura, która poprzez nowo tworzone kompleksy łączy różne obszary życia społecznego. Ośrodki kulturalne tworzą bardzo często nowe przestrzenie, zmieniając dotychczasowy, przemysłowy wizerunek miasta. Mówiąc o kulturze jako czynniku wpływającym na rozwój jednostki samorządu terytorialnego, pamiętać należy, iż współcześnie jest ona integralną częścią turystyki, zwłaszcza w odniesieniu do przestrzeni kultury powstałych np. w dawnych obiektach poprzemysłowych. Wpływa także na tworzenie nowej marki ośrodka, poprzez sukcesję funkcji gospodarczych. Celem artykułu jest identyfikacja funkcji kulturalnej Zabrza, w nietypowej, podziemnej przestrzeni byłej kopalni węgla kamiennego - kopalni „Guido”. Omówiony przykład przekształceń obiektu przemysłowego i jego podziemi rzuca nowe światło na wykorzystanie starych, nieatrakcyjnych terenów pogórniczych i jednocześnie ukazuje sukcesję funkcji z przemysłowej na kulturalną.
\end{abstract}

Słowa kluczowe: kopalnia „Guido”, Zabrze, kultura, turystyka industrialna, turystyka poprzemysłowa.

\section{UNDERGROUND CULTURAL SPACE IN THE GUIDO MINE IN ZABRZE}

Abstract: The contemporary development of urban centres is the result of the impact of many factors, which to a greater or lesser extent are determined by the management of local authorities. Among these determinants, culture plays a special role as it combines various areas of social life often creating new spaces, changing the current industrial image of Zabrze. When discussing culture as a factor in the development of local government, it should be remembered that today it is an integral part of tourism, especially in relation to the cultural spaces created, for example, in former industrial facilities. It also influences the creation of a new brand image through new economic functions succeeding those of the past. The aim of the article is to identify the cultural function of Zabrze in the unusual underground space of the Guido coal mine. The example of the transformation of an industrial facility and its underground part sheds new light on old unattractive former mining areas and at the same time shows functional succession from industrial to cultural.

Keywords: Guido mine, Zabrze, culture, industrial tourism, post-industrial tourism.

\section{WPROWADZENIE}

Współczesny rozwój miast to skomplikowany proces wprowadzania zmian, mający na celu podniesienie atrakcyjności danego obszaru. Budowanie przewagi konkurencyjnej opiera się między innymi na rzadkich, lokalnie zakorzenionych i trudnych do przeniesienia zasobach. Należą do nich między innymi kultura, powstała w oparciu o obiekty poprzemysłowe, jak również turystyka. Nowo utworzone przestrzenie implikują w znacznym stopniu dynamikę i kierunek rozwoju społeczno-ekonomicznego miast. Współcześnie rozumienie turystyki coraz częściej odbiega od klasycznej definicji, według której jest to podróżowanie dla przyjemności, w celu poznania nieznanych dotąd miejsc czy odpoczynku od pracy zawodowej. Dziś jest to, ograniczana jedynie przez wyobraźnię, forma spędzania czasu, która stała się potężnym rynkiem przemysłowym, finansowym i kulturowym. Istotą tak postrzeganej turystyki jest atrakcyjność polegająca na nieustannym zaskakiwaniu zwiedzającego. Tworzenie możliwości zrealizowania przez turystę nietypowych i niedostępnych działań wpisuje się w ekonomię doświadczeń, zwłaszcza gdy mowa - tak jak w niniejszym artykule - o terenach poprzemysłowych (Stasiak, 2019). W Górnośląsko-Zagłębiowskiej Metropolii znajduje się wiele obiektów poprzemysłowych, stanowiących dziedzictwo kulturowe regionu, które zostały zagospodarowane w sposób 
niekonwencjonalny, dzięki czemu turyści mogą poznać bardzo specyficzną przestrzeń. Warto tu zwrócić uwagę na szersze znaczenie sformułowania obiekty poprzemysłowe. Według Lamparskiej (2017) są to wielkogabarytowe budowle, linie przesyłowe, komunikacyjne, kompleksy fabryczne, osiedla robotnicze, tereny poeksploatacyjne, powierzchniowe i podziemne kopalnie wraz z infrastrukturą technologiczna, tereny, na których w wyniku działalności przemysłowej zachwiano równowagę procesów geologicznych, hydrograficznych, glebowych, biologicznych. Chmielewska (2010), badając przestrzeń przemysłową w miastach konurbacji katowickiej, wydzieliła cztery typy obiektów przemysłowych funkcjonujących w obrębie miast: tereny po zakładach przemysłowych, pojedyncze elementy zabudowy zakładów przemysłowych, zabudowę towarzyszącą $\mathrm{w}$ postaci osiedli patronackich oraz nieużytki poprzemysłowe. Obiekty te stanowią współcześnie obszar badawczy w ujęciu geografii społeczno-ekonomicznej, jak również turystycznej, gdzie wiele uwagi poświęca się wartościom krajobrazowym i turystycznym (Myga-Piątek, 2016). Siedem polskich obiektów, wyróżniających się szczególnymi walorami, zostało umieszczonych na Europejskim Szlaku Dziedzictwa Przemysłowego. Sieć ta łączy obiekty dziedzictwa przemysłowego o szczególnym znaczeniu historycznym i potencjale turystycznym, zwracając uwagę na wspólne europejskie dziedzictwo przemysłowe. Trzy z nich znajdują się w obrębie Górnośląsko-Zagłębiowskiej Metropolii w województwie śląskim, są to: Zabytkowa Kopalnia Srebra w Tarnowskich Górach, Tyskie Browarium oraz Zabytkowa Kopalnia Węgla Kamiennego "Guido" w Zabrzu. Ten fakt był przesłanką do podjęcia problemu przekształceń dawnej kopalni w „nową jakość" - obiekt turystyczny, pełniący rolę usługową. Celem artykułu jest identyfikacja funkcji kulturalnej miasta Zabrza, w nietypowej, podziemnej przestrzeni byłej kopalni węgla kamiennego - kopalni „Guido”. Opisywany przykład przekształceń obiektu przemysłowego i jego podziemi rzuca nowe światło na stare, nieatrakcyjne tereny pogórnicze i jednocześnie ukazuje sukcesję funkcji z przemysłowej na kulturalną. Dodatkowo wpływa na budowanie nowej, rozpoznawalnej w regionie i kraju marki Zabrza, opierającej się na genezie miasta. W opracowaniu wykorzystano zarówno metody ilościowe, jak i jakościowe, które umożliwiły ukazanie nietypowej przestrzeni kulturalnej. Wśród nich znalazła się analiza ilościowa aktualnej oferty kopalni "Guido" dotycząca ruchu turystycznego w obiekcie oraz szczegółowa analiza wydarzeń kulturalnych tam się odbywających. Wspomniane analizy ilościowe sporządzono na podstawie danych statystycznych pozyskanych z kopalni „,Guido”.

Niniejsze opracowanie składa się z trzech części, pierwsza poświęcona jest pojęciu kultury i jej wpływowi na rozwój miasta. Opisuje koncepcję kreatywnej Europy, w której ważne są związki kultury z dziedzictwem przemysłowym. Druga część ukazuje genezę turystyki industrialnej w Zabrzu na przykładzie kopalni „Guido", którą charakteryzują trzy funkcje: turystyczna, edukacyjna i kulturowa. Szczególną uwagę zwraca bardzo nietypowa działalność kulturalna - prowadzona jest w byłych komorach górniczych pod ziemią. W końcowej części opracowania zwrócono uwagę na inne obiekty poprzemysłowe w Europie i w Polsce, które podobnie jak kopalnia ",Guido" zostały przekształcone m.in. w instytucje świadczące usługi kulturalne.

\section{POJĘCIE KULTURY \\ I JEJ WPŁYW NA ROZWÓJ MIASTA - UJĘCIE TEORETYCZNE}

Pojęcie kultury wywodzi się z łacińskiego słowa cultura i dosłownie oznacza uprawę lub kształcenie (Kultura, 1971). Najczęściej pojęciem tym określany jest całokształt materialnego i duchowego dorobku społeczeństwa. Na kulturę w ujęciu materialnym składają się wytwory człowieka, technika i umiejętności praktyczne. Wówczas możemy mówić o osiągnięciach społeczności, mających odzwierciedlenie w budynkach i budowlach, książkach, obrazach, rzeźbach, układach przestrzennych, umiejętnościach, rozwiązaniach technicznych itp. W przypadku kultury niematerialnej można mówić o sposobach myślenia, symbolach, wzorach zachowania, współpracy, motywowaniu do działania, solidarności, wiedzy, piśmiennictwie, sztuce, prawie, pięknie, poczuciu dobra. Człowiek tworzy kulturę, a zarazem jest jej odbiorca, dzięki innym członkom społeczeństwa (Karwińska, 2013). Dorobek społeczności podlega nieustannej ewolucji, z jednej strony nadążając za współczesnymi przeobrażeniami, z drugiej tworząc nowe trendy w sztuce, architekturze, nauce czy gospodarce. Kultura jest podstawą regulacji stosunków społecznych, elementem składającym się na jakość życia i w takim rozumieniu nie ma charakteru wartościującego. Jest dziedziczona społecznie, a obejmuje swoim zakresem wszystkie rytuały religijne, normy społeczne, wyznawane powszechnie wartości oraz dorobek materialny. Rozpoznanie związków zachodzących między sferą kultury a gospodarką pozwala zrozumieć, dlaczego w pewnych uwarunkowaniach przyczynia się ona do rozwoju społeczno-gospodarczego kraju, w tym miast. Wilkin (2016a) stwierdza, że gospodarka to część kultury, a gospodarowanie jest silnie zakorzenione w kulturze. Człowiek pozostaje z nią w związku, gdyż najważniejsze instytucje charakteryzują się dużą trwałością i znaczeniem społecznym (np. uniwersytety) i duchowym (np. kościoły). Kultura kształtuje rzeczywistość społeczną oraz determinuje jakość życia. Zaś najważniejszymi wytworami życia 
społecznego, wyznaczającymi podstawy zachowań ludzi są instytucje (Stawasz, 2017; Wilkin, 2016b). Podlegają one ewolucji, co wynika z uczenia się i zmiennych warunków, w jakich funkcjonują społeczności. Zmiany instytucjonalne umożliwiają i wyznaczają rozwój społeczno-gospodarczy, natomiast inercja i niesprawność instytucji to hamulec rozwoju. Mechanizmy rynkowe zależą od jakości i spójności instytucjonalnych ram jego funkcjonowania. System instytucjonalny rozumiany jako układ skomplikowanych powiązań wyznacza przestrzeń, jak i bodźce ludzkiego działania, a gospodarowanie jest zakorzenione w kulturze, która nadaje znaczenie pojęciom, procesom, wartościom (np. w zakresie własności, sprawiedliwości). Pojęcie równowagi instytucjonalnej dobrze wyjaśnia kwestie trwałości i zmienności oraz systemów gospodarczych, przy czym trzonem równowagi instytucjonalnej staje się kultura. Najistotniejszy wpływ na zachowania człowieka mają trzy elementy oddziaływania: rynek, państwo i kultura (Karwińska, 2013).

Sektor kultury reguluje stosunki między uczestnikami życia w mieście oraz dostarcza usługi, mające zaspokajać szereg potrzeb mieszkańców, inwestorów, turystów itp. (Scott, 1997). Konsumpcja dóbr kultury wytworzonych na danym obszarze może też wpływać na całą lokalną czy regionalną społeczność, która nie bierze udziału $\mathrm{w}$ tworzeniu kultury. $\mathrm{W}$ tym miejscu warto odnieść się do koncepcji efektów zewnętrznych. Opisuje ona wpływ transakcji między oferentem i konsumentem na osoby trzecie. W świetle założeń kultura wzbogaca nie tylko konsumentów, ale jest źródłem efektów zewnętrznych, które stają się odczuwalne przez ogół społeczeństwa. Mogą one mieć pozytywny albo negatywny charakter, choć należy przyznać, że w przypadku sektora kultury dominują efekty pozytywne. W ekonomice kultury rozróżnia się efekty oddziałujące na życie gospodarcze poprzez popyt i podaż (Borowiecki, 2004). Dla przykładu, dzięki tzw. turystyce kulturalnej miast, w których znajdują się unikatowe obiekty i układy architektoniczne oraz odbywają się znaczące wydarzenia kulturalne, szybciej rozwija się zarówno strona podażowa (oferta hoteli, gastronomii, przemysłu pamiątkarskiego, turystycznego itp.), jak i popyt na usługi i żywność (Sheng, Wang, 2017). Konsumpcja usług kultury niesie za sobą również wielorakie korzyści dla odbiorców. Uczestnicy kultury, często korzystając z różnego typu usług, stają się bardziej kreatywni, innowacyjni, przedsiębiorczy, krytyczni wobec otaczających ich zjawisk społecznych i gospodarczych. Konsumenci kultury mogą również pośrednio oddziaływać na swoje środowiska społeczne, na grupy odniesienia i przekazywać wybrane treści zasłyszane czy postawy zaobserwowane podczas uczestniczenia w rozmaitych wydarzeniach kulturalnych. Równie często podnoszą konkurencyjność organizacji prywatnych, publicznych i społecznych. Nowe inwestycje w obiekty badawczo-rozwojowe, nowoczesne przedsiębiorstwa czy inne aktywności gospodarcze mają miejsce w ośrodkach, w których oferta kulturalna plasuje się na wysokim poziomie. Opisane w literaturze przedmiotu społeczne funkcje kultury pozwalają na zidentyfikowanie następujących kategorii pozytywnych efektów zewnętrznych związanych z konsumpcją dóbr kultury (Strycharz, 2013): stymulacja pomysłów kreatywnych i wyobraźni, dostarczanie standardów estetycznych, poprawa postaw społecznych odbiorców, pobudzanie do dyskusji oraz krytyczna ocena rzeczywistości. Dodać można również: zmianę zainteresowań i sposobu spędzania czasu wolnego, wzrost zdolności do absorpcji nowych produktów, zwracanie uwagi na estetykę miejsca, ład i porządek przestrzeni publicznych, docenianie walorów środowiska naturalnego, stosunek do dóbr publicznych. Zgodnie z wywodem Tofflera (1986) kultura trzeciej fali nastawiona jest na zmianę i rosnąca różnorodność - próbuje połączyć ze sobą nowe poglądy na przyrodę, ewolucję i postęp. Zatem kultura łączy społeczności i osiągnięcia poprzednich pokoleń z tym, co ważne tu i teraz oraz wywiera istotny wpływ na formułowanie nowej, rodzącej się kultury przyszłości. Konsumpcja dóbr kultury jest celem samym w sobie, przyczynia się do rozwoju intelektualnego odbiorcy, wyzwala pozytywne emocje, pozwala na przeżycie czegoś wyjątkowego, stymuluje procesy twórczego myślenia. Poziom kreatywności społeczeństwa determinuje zdolność do tworzenia i dostosowywania się do nowych warunków ekonomicznych. Przejawia się to $\mathrm{w}$ zmianie struktur gospodarczych, prowadzaccych w kierunku rozwoju przemysłów kreatywnych, odznaczających się wysoką wartością dodaną (Głowac$\mathrm{ki}, 2017)$.

\section{ROLA KULTURY W ŚWIETLE KONCEPCJI „KREATYWNEJ EUROPY”}

Przemiany zachodzące $\mathrm{w}$ przestrzeniach miast poprzemysłowych Górnośląsko-Zagłębiowskiej Metropolii wpisują się w europejski model budowy miast „Kreatywna Europa" (Creative Europe). Ta koncepcja powstała w European Institute for Comparative Curtural Research w niemieckim Köln. W założeniu tym zwraca się uwagę na rolę i zarządzanie kultura, na procesy innowacyjności oraz rozwoju urbanistycznego z zachowaniem dziedzictwa kulturowego. Istotne jest też skuteczne zarządzanie kulturą w wymiarze lokalnym i krajowym. Zgodnie z tą wizją, powinno dochodzić do łączenia dokonań i opinii w sprawie kształtowania gospodarki przedstawicieli różnych dziedzin kultury, socjologii, urbanistyki i innych (Namyślak, 2013). Ważne wydają się związki turystyki z kulturą. Przecławski (1997) podkreśla, że turystyka jest: 
- funkcją kultury,

- elementem kultury,

- przekazem kultury,

- spotkaniem kultur,

- czynnikiem przemian kulturowych.

Tego typu podejście do kultury jest zgodne z czynnikami wewnętrznymi rozwoju lokalnego, które współcześnie jest bardzo ważne zwłaszcza w miastach poprzemysłowych. Według Gorzelaka (2000) najważniejszą rolę pełnią $\mathrm{w}$ nim:

- lokalni liderzy i tzw. aktorzy lokalni, którzy powinni stanowić elitę odpowiedzialną za miejscową strategię prorozwojową i jej realizowanie;

- instytucje lokalne utrzymujące dynamikę i strukturę rozwoju miejscowego, wspierające przedsiębiorczość (np. inkubatory) czy wzbogacające tkankę społeczną (stowarzyszenia, kluby, zespoły);

- aktywna społeczność lokalna oraz zintegrowana społeczność lokalnych przedsiębiorców;

- skłonność do współpracy, szczególnie z sąsiadami.

W świetle przedstawionych rozważań stwierdzić należy, iż współcześnie kultura staje się ważnym czynnikiem rozwoju lokalnego, regionalnego i ponadregionalnego miast - zwłaszcza poprzemysłowych. Co więcej, władze samorządowe tworzą swoją obecną politykę rozwoju miast, opierając się na dziedzictwie kulturowym, które traktują jako punkt wyjścia do kreowania nowych przestrzeni z zachowaniem historii regionu. Połączenie tych elementów wpisuje się w turystykę kulturową. Można ją rozpatrywać jako kreatywne wykorzystanie dawnych przestrzeni przemysłowych poprzez tworzenie nowych funkcji, bardzo zróżnicowanych, wielowymiarowych i ograniczonych jedynie ludzką wyobraźnią. Zrewitalizowana przestrzeń - jak np. poprzemysłowa architektura, stare układy zabudowy, kubatura obiektów i ich monumentalizm, rozplanowanie oraz łączenie starych i nowych aranżacji - ukazuje unikatowość miasta, jego niepowtarzalność Tego typu nowe projekty, oparte na bazie dziedzictwa kulturowego regionu, i działania z nimi związane dają możliwość tworzenia przestrzeni stających się często nowymi markami miast na arenie krajowej, a nawet międzynarodowej. Coraz częściej do promocji miast i regionów poprzemysłowych, jak również tworzenia marki wykorzystuje się nowatorską przestrzeń i infrastrukturę kulturalną (Jokela, 2018). Wykorzystanie przestrzeni kulturalnej, rozumianej jako część przestrzeni geograficznej ma na celu zwiększenie pozycji obszaru nie tylko w regionie czy kraju, ale także na arenie europejskiej i w globalnej sieci miast. Sama przestrzeń daje ku temu podstawy, zwłaszcza jeśli odniesiemy się do jej definicji zaproponowanej przez Lisowskiego (2003). Wskazuje on bowiem, że przestrzeń (podobnie jak czas) jest przede wszystkim kategorią społeczną. Po pierwsze jest sposobem myślenia o świecie, kategoria poznania według Kanta, a po drugie emanacją życia społecznego. W pierwszym przypadku jest kategorią koordynującą dane doświadczeń zmysłowych, klasyfikując je na części bądź kierunki wraz z przypisanymi im wartościami i znaczeniami. W drugim przypadku przestrzeń (wytworzona przez człowieka) jest medium organizującym życie społeczne i środkiem reprodukcji stosunków społecznych. Zaproponowana definicja w sposób naturalny wskazuje na dużą korelację między działalnością twórczą człowieka a przestrzenią. Budowanie $w$ ten sposób marki miasta wpisuje się $\mathrm{w}$ tworzenie przewagi konkurencyjnej (Szafranek, 2019) na podstawie wartości niematerialnych, takich jak: wiedza, innowacyjność i kreatywność.

Rozpatrując kulturę w świetle koncepcji „Kreatywnej Europy" nie sposób nie odnieść się do pojęcia turystyki kulturowej, która obecnie stanowi istotny czynniki rozwoju miast. Nazwą turystyki kulturowej możemy określić wszystkie grupowe lub indywidualne wyprawy o charakterze turystycznym, w których spotkanie uczestników podróży z wytworami kultury albo powiększenie wiedzy o zorganizowanym przez człowieka świecie otaczającym jako jej wytworze jest zasadniczą częścią programu podróży lub stanowi rozstrzygający argument dla indywidualnej decyzji o jej podjęciu lub wzięciu w niej udziału (von Rohrscheidt, 2010). Wspomniany rozwój urbanistyczny, zachowujący dziedzictwo kulturowe obszaru, stwarza zatem idealne warunki do rozwoju turystyki kulturowej na terenach poprzemysłowych.

\section{OBSZAR BADAŃ, MATERIAŁY ŹRÓDŁOWE I ZAKRES CZASOWY}

Opracowanie poświęcone jest strefie podziemnej byłej Kopalni Węgla Kamiennego „Guido”, która jest położona w środkowo-południowej części Zabrza. Miasto wchodzi w skład nowo utworzonej Górnośląsko-Zagłębiowskiej Metropolii (rys. 1), skupiającej 41 gmin różnej wielkości. Ta struktura ma swe podłoże w konurbacji katowickiej (Runge, 2016), w której Zabrze odgrywało istotną rolę gospodarczą $\mathrm{w}$ okresie industrializacji, obok takich miast, jak m.in. Gliwice, Bytom, Chorzów czy Katowice. Jako ośrodek poprzemysłowy z licznymi problemami społeczno-gospodarczymi Zabrze wciąż zaliczane jest do miast dużych, chociaż charakteryzuje się depopulacja, na co zwraca uwagę Runge (2015). W 2020 r. liczyło ponad 171 tys. osób, od momentu odnotowania w 1991 r. największej liczby ludności do 2020 r. liczba ta zmalała o 34 tys.

Podjęte zagadnienie udostępniania kultury w Zabrzu porusza rozwój tzw. usług wyższego rzędu i wpisuje się $\mathrm{w}$ podnoszenie jakości życia poprzez wzbogacenie 
oferty kulturalno-rozrywkowej. Podstawowym materiałem źródłowym były dane o liczbie wydarzeń kulturalnych zorganizowanych na terenie kopalni w 2017 i 2018 r., wraz z liczbą ich uczestników, pozyskane z Muzeum Górnictwa Węglowego w Zabrzu. Informacje te umożliwiły określenie dynamiki wzrostu wydarzeń odbywających się pod ziemią i wskazać trendy aktywności rocznej. Wykorzystano także dane o podziemnych atrakcjach turystycznych, które współtworzą lub wzbogacają wydarzenia kulturalne. Niestety dane dotyczące kopalnia "Guido” zbierane są od niedawna, a dodatkowo stanowią część ogólnego zbioru informacji odnoszącego się do Muzeum Górnictwa Węglowego w Zabrzu jako jednej jednostki kulturalnej. Z tego powodu dane wykorzystane $w$ opracowaniu dodatkowo zweryfikowano pod kątem wydarzeń kulturalnych odbywających się tylko w obiekcie Kopalni Węgla Kamiennego "Guido", skorzystano przy tym z informacji publikowanych na stronach internetowych obiektu. Według tych informacji kopalnię rocznie odwiedza ponad 120 tys. osób, a szacuje się, że liczba turystów wrośnie do 250 tys. osób (Kopalnia „Guido”, 2020).

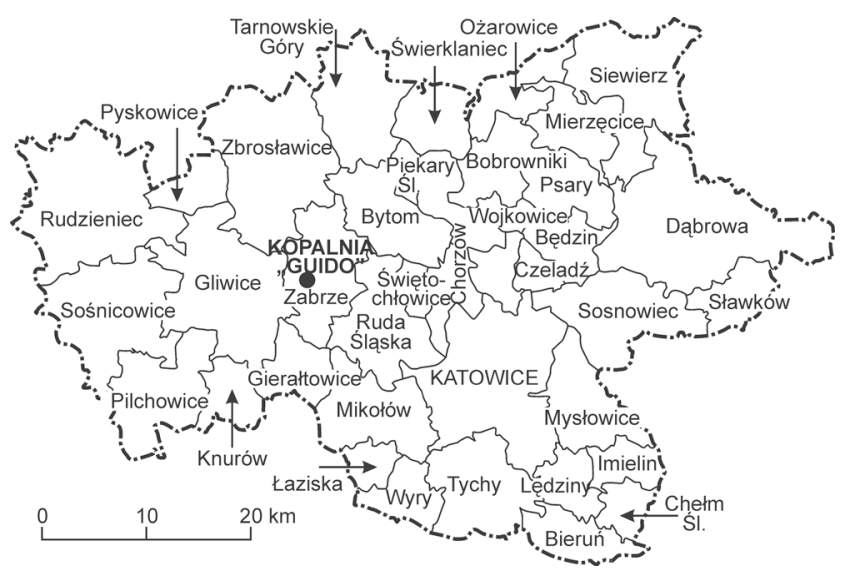

Rysunek 1. Lokalizacja Kopalni Węgla Kamiennego "Guido” w przestrzeni Górnośląsko-Zagłębiowskiej Metropolii Źródło: opracowanie własne

\section{ZABRZE - MIASTO TURYSTYKI PRZEMYSŁOWEJ}

Obecnie polityka prowadzona przez władze Zabrza skoncentrowana jest na rozwoju w dwóch kierunkach. $\mathrm{Z}$ jednej strony aspiruje się do stworzenia $\mathrm{w}$ mieście wyraźnego zaplecza przemysłu nowych technologii, stąd też duży wysiłek kładziony jest na tworzenie terenów inwestycyjnych oraz Specjalnej Strefy Ekonomicznej. Z drugiej strony miasto chciałoby pełnić istotną rolę turystyczna, wykorzystując dziedzictwo przemysłowe. Rozwój funkcji turystycznej jest następstwem restrukturyzacji gospodarki przemysłowej, po długim i intensywnie rozwijającym się na przełomie XIX i XX w. okresie industrializacji. Samorząd lokalny pokłada nadzieje w rozwoju nowej funkcji, będącej uzupełnieniem pozostałych działalności, która pomogłaby w promowaniu Zabrza jako miasta turystyki przemysłowej. Trudno zaprzeczyć idei tej promocji, mając na względzie liczne obiekty przemysłowe, posiadające dziś status zabytków kultury. Wśród nich znajdują się dwie wieże ciśnień, wieża wyciągowa i maszynownia szybu „Maciej”, dwie kopalnie: „Guido” i „Królowa Luiza" oraz pięć osiedli robotniczych, z czego najsłynniejsza jest kolonia patronacka Ballestrema w dzielnicy Rokitnica, wzniesiona w latach 1905-1913. Obecnie cieszą się one stosunkowo dużym zainteresowaniem wśród turystów, choć pełnią głównie rolę przestrzeni mieszkaniowej i w mniejszym stopniu turystycznej. Także inne miasta regionu posiadają podobne osiedla, tylko w obrębie Katowic zidentyfikowano aż 34 tego typu zabudowy, z czego do dzisiaj przetrwało 9. Do najbardziej znanych zalicza się Giszowiec i Nikiszowiec (Chmielewska, 2009). Możliwość ich zobaczenia wraz z zakładem poprzemysłowym pozwala odbiorcy na lepsze zrozumienie codziennego rytmu życia pracownika kopalni.

Zabrze promowane jest hasłem: „Miasto Turystyki Przemysłowej". Najistotniejszą rolę w rozwoju turystyki industrialnej miasta odgrywa Muzeum Górnictwa Węglowego, będące jednocześnie największą instytucją turystyczno-kulturalną w Zabrzu. W kwietniu 2013 r. połączono Zabytkową Kopalnię Węgla Kamiennego "Guido" z Muzeum Górnictwa Węglowego, tworząc jeden podmiot. W skład nowej instytucji wszedł także kompleks Sztolnia „Królowa Luiza”, który po całościowej rewitalizacji stał się obok kopalni „Guido" jedną z najciekawszych atrakcji turystycznych miasta. Składa się on z wyrobisk kopalni „Królowa Luiza” oraz Głównej Kluczowej Sztolni Dziedzicznej. Od momentu połączenia tych instytucji $w$ jeden podmiot turystyczno-kulturalny miasto rozpoczęło prace nad tworzeniem wyjątkowej przestrzeni turystycznej zarówno na powierzchni, jak i pod ziemią.

Kopalnia "Guido" stanowi obecnie najbardziej charakterystyczny i rozpoznawalny obiekt miasta. By zrozumieć współczesny fenomen tego miejsca, niezbędne wydaje się odniesienie do jego genezy. Początki kopalni sięgają 1855 r., kiedy to hrabia Guido Henckel von Donnersmarck, magnat i przemysłowiec, założył w Zabrzu kopalnię węgla kamiennego nazwaną jego imieniem.

Budowa szybów „Barbara” i „Concordia” (przemianowany później na "Guido”) wiązała się z pokonywaniem licznych problemów. Najpierw, po wykonaniu zaledwie 30 metrów szybu, napotkano kurzawkę i natrafiono na uskok „Saara”, co spowodowało, że w 1856 r. przerwano drążenie. Założony został pierwszy poziom wydobywczy $80 \mathrm{~m}$ w szybie "Guido". Zaburzenia 
tektoniczne utrudniały jednak wydobycie. W 1862 r. na głębokości $117 \mathrm{~m}$ szyb „Guido" przerwał warstwę wodonośną i został zatopiony. Aby zgromadzić kapitał inwestycyjny na dalsze roboty górnicze, powstała spółka z Górnośląskim Towarzystwem Kolejowym (Oberschlesische Eisenbahn Gesellschaft). W 1870 r. przystąpiono do osuszenia szybu i jego dalszego zgłębiania do $170 \mathrm{~m}$, aby w 1872 r. wznowić wydobycie na poziomie $80 \mathrm{~m}$. Równocześnie trwały prace związane z drążeniem szybu, który dziś wykorzystywany jest w celach turystycznych. W latach 1885-1887 kopalnia "Guido" została wykupiona przez Skarb Pruski i włączona jako pole południowe do państwowej kopalni „Królowa Luiza”. Dostępne zasoby na poziomie $170 \mathrm{~m}$ były w znacznej mierze już wybrane i w ramach kopalni „Królowa Luiza” przystąpiono do połączenia z poziomem 320 m. W 1912 r. kopalnię „Guido" przyłączono do nowo wybudowanej kopalni i koksowni „Delbrück” (Hnatyszyn, 2002).

Po podziale Śląska w 1922 r. kopalnia „Delbrück” $\mathrm{z}$ "Guido" znalazła się po stronie niemieckiej i została przekazana pruskiemu koncernowi Preussag. W 1928 r. szyb Guido został unieruchomiony, ale pozostał szybem zjazdowym dla załogi i materiałów, zaś na poziomie $170 \mathrm{~m}$ zainstalowano urządzenia odwadniające dla całej kopalni. Po 1945 r. obiekt nazwano Kopalnią Węgla Kamiennego "Makoszowy”, a rejon dawnej kopalni "Guido" stracił na znaczeniu (Hnatyszyn, 1999). Do ponownego ożywienia doszło w 1967 r., kiedy utworzono Kopalnię Doświadczalną Węgla Kamiennego „M-300”, w której testowano nowe urządzenia i maszyny górnicze, dostarczając przy tym niewielką ilość wydobycia.

W 1982 r. na poziomie $170 \mathrm{~m}$ utworzony został Skansen Górniczy "Guido", udostępniony do zwiedzania, a następnie wpisany do rejestru zabytków. W 2000 r., na fali obniżania kosztów w przemyśle węglowym, przystąpiono do demontażu unikatowej, podziemnej kopalni, którą można było zwiedzać. Jednakże zaangażowanie wielu instytucji, przede wszystkim samorządu miejskiego Zabrza, Urzędu Marszałkowskiego Województwa Śląskiego i osób prywatnych, doprowadziło do zatrzymania likwidacji i utworzenia w $2007 \mathrm{r}$. Zabytkowej Kopalni „Guido” jako samodzielnej instytucji kultury miasta Zabrza i województwa śląskiego. Obecnie jest to światowej klasy zabytek, stanowiący nie tylko jedno z najciekawszych miejsc na Szlaku Zabytków Techniki Województwa Śląskiego, ale jeden z 850 obiektów europejskiego dziedzictwa przemysłowego, tworzącego Europejski Szlak Dziedzictwa Przemysłowego (ang. European Route of Industrial Heritage, ERIH). Marka kopalni „Guido" to efekt kreatywnego wykorzystania przestrzeni obiektu przemysłowego, polegającego m.in. na organizacji imprez i koncertów w czterech komorach górniczych na poziomie $320 \mathrm{~m}$.

\section{WYNIKI BADAŃ}

Na ofertę kopalni "Guido" składają się: zwiedzanie podziemi, które można zaliczyć do funkcji turystycznej, edukacja skierowana do dzieci i młodzieży oraz rozrywka i wypoczynek, które zaliczają się do funkcji kulturalnej i rekreacyjnej.

Działalność turystyczna obejmuje całą kopalnię. Turyści zjeżdżają pod ziemię $\mathrm{w}$ asyście przewodnika z zachowaniem wszelkich zasad bezpieczeństwa, mają do wyboru trzy trasy zwiedzania. Pierwsza nastawiona jest na poznawanie dobrze zachowanych poziomów wydobywczych $170 \mathrm{~m}$ i $320 \mathrm{~m}$, do których turysta udaje się szola, czyli windą. W czasie około trzygodzinnej podziemnej wędrówki do najistotniejszej części poziomu 170 m uczestnik ma możliwość zapoznania się z interesującą historią kopalni oraz specyfiką pracy górnika z początku XX w. Punktem kulminacyjnym poziomu jest kaplica świętej Barbary, wyróżniająca się ze względu na walory architektoniczne. Co ciekawe, znajduje się ona w grupie śląskich centrów pielgrzymkowych i stanowi cel wędrówek. $Z$ punktu widzenia zagospodarowania jest to przestrzeń sacrum o funkcji religijnej. $W$ drugiej części trasy turysta może poznać rozwój techniki górniczej od końca XIX w. aż do czasów współczesnych. Częścią integralną są pokazy pracy wielkich maszyn górniczych (np. kombajnu) i przejazd elektryczną kolejką podwieszaną. Zwiedzanie kopalni "Guido" kończy się w najgłębiej położonym pubie w Europie. Jest to specjalnie wydzielona przestrzeń gastronomiczna o funkcji rekreacyjno-wypoczynkowej, wyróżniająca się nietypowym wnętrzem, np. stoły zostały specjalnie zaprojektowane, są na kółkach i mogą wjeżdżać w wykutą wnękę skalną. Charakterystyczny wystrój wykorzystuje przestrzeń podziemną i nawiązuje do elementów górniczych oraz bardzo modnego obecnie w Polsce stylu industrialnego. Dzięki temu, że lokal znajduje sią pod ziemią nie ma ograniczeń grubości ścian, wyróżnia się specyficznymi wąskimi korytarzami, panuje tam półmrok i niespotykana przestrzeń oraz akustyka.

Kopalnia systematycznie wzbogaca ofertę turystyczną. Pracownicy i przewodnicy wykazują dużą kreatywność, która znajduje swoje odzwierciedlenie w uatrakcyjnianiu tras zwiedzania, jak i tworzeniu zupełnie nowych produktów usługowych. W ofercie kopalni znalazły się dwie propozycje nieco bardziej ekstremalnych form zapoznawania się z przemysłowym dziedzictwem kulturowym. Trasa Mroki Kopalni (fot. 1) jest wyprawą w najgłębsze i najbardziej surowe rejony kopalni "Guido". Turysta, decydując się na uczestnictwo w tej formie zwiedzania, udaje się w najdalsze obszary kopalni, gdzie panują bardziej ekstremalne warunki. Z jednej strony niskie, niedostępne korytarze silnie oddziałują na wyobraźnię odwiedzających, z drugiej wymagają od uczestnika wyprawy sprawności fizycznej. 


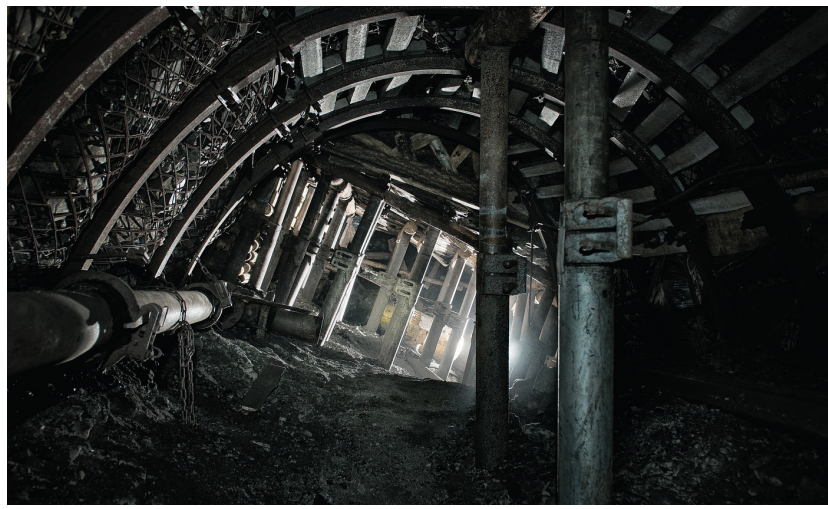

Fotografia 1. Fragment trasy Mroki Kopalni Zródło: Mroki Kopalni - trasa tymczasowo wstrzymana (2020)

Dla turysty, który chce doświadczyć pracy górnika, przygotowano czterogodzinną szychtę, czyli typowy dzień pracy pod ziemią. Uczestnik wycieczki musi wykonać kilka zadań praktycznych, takich jak te, które należały do obowiązków pracownika zmianowego. Przed zjazdem turysta otrzymuje pełny ekwipunek i strój sztygarski, następnie rusza do najgłębiej położonych rejonów kopalni "Guido" i wykonuje typowe prace górnicze. Jego zadaniem jest m.in. przeniesienie rurociągu o wadze kilkudziesięciu kilogramów, montaż przenośnika taśmowego, przycięcie drewnianego stempla, zabudowa lutni wentylacyjnej i inne prace zlecone przez sztygara (fot. 2).

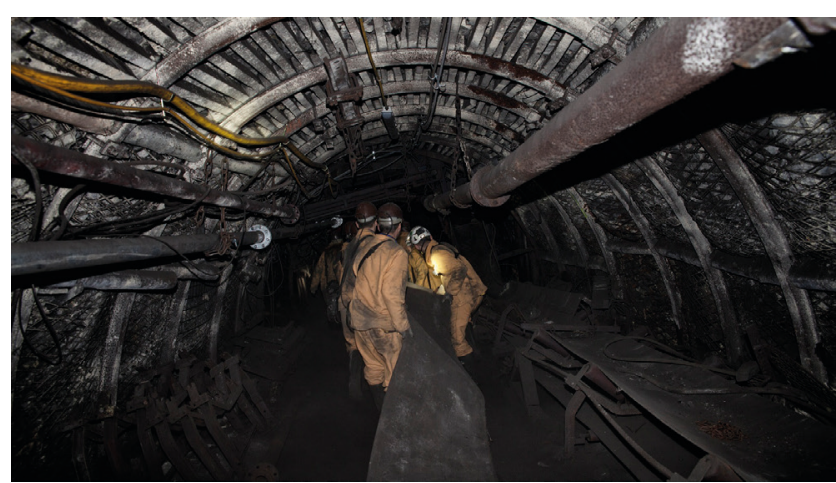

Fotografia 2. Przeniesienie elementu taśmociągu w czasie górniczej szychty

Źródło: Szychta - tymczasowo wstrzyma (2020)

Oprócz funkcji turystycznej, istotnym elementem działalności kopalni jest edukacja. Kopalnia we współpracy z Muzeum Górnictwa Węglowego w Zabrzu przygotowała ofertę dla dzieci i młodzieży szkolnej. Obejmuje ona problematykę związaną z przeszłością historyczną regionu i miasta. Istotne jest, że odnosi się ona do edukacji regionalnej i łączy z przeszłością przemysłową obszaru. Porusza szereg zagadnień nawiązujących do genezy regionu, rozwoju Zabrza oraz wielu innych elementów tożsamości regionalnej. Przygotowana oferta edukacyjne cechuje się także nowoczesnym przekazem $\mathrm{w}$ formie interaktywnej (Koman,
2015). Ponadto kopalnia, oprócz projektów edukacyjnych realizowanych wspólnie z Muzeum Górnictwa Węglowego, oferuje też własne zajęcia skierowane do uczniów, które są zintegrowane z podstawą programową kształcenia ogólnego. Przykładem jest trasa edukacyjna, której treści opracowane zostały na podstawie kształcenia ogólnego dla III i IV etapu edukacyjnego. „Bezpieczna historia węgla" - to nazwa specjalistycznej trasy edukacyjnej, w trakcie której uczniowie mają możliwość nie tylko zapoznania się z zasobami kopalni, ale również biorą udział w projekcji filmów edukacyjnych, warsztatach na temat węgla i jego obiegu w przyrodzie oraz warsztatach z zakresu udzielania pierwszej pomocy medycznej. Trasa ta znajduje się na poziomie $170 \mathrm{~m}$ kopali "Guido", a czas jej trwania to około dwie godziny lekcyjne. Propozycja ta wpisuje się w działalność kreatywną, rozumianą jako przygotowanie autorskiego programu na bazie kultury materialnej.

Trzecim typem działalności kopalni "Guido", najnowszym, a zarazem najciekawszym, jest działalność kulturalna. Przestrzeń kopalni staje się ciekawym miejscem spotkań zarówno odbiorców kultury, jak i jej twórców. Pod ziemią organizowane są różne wydarzenia kulturalne i tematyczne, wśród których można znaleźć m.in. koncerty muzyki dawnej, rockowej z kraju i ze świata, instrumentalnej, spotkania autorskie z lokalnymi i światowej sławy pisarzami, integracyjne spotkania kulturalne różnych grup społecznych, w tym lokalnych pasjonatów oraz imprezy tematyczne związane z kulturą górnicza, środowiskiem przyrodniczym, eksploatacją surowców mineralnych, kulturą regionu i inne. W 2017 i 2018 r. kopalnia "Guido" zorganizowała ponad 400 wydarzeń kulturalnych, w których uczestniczyło 24,2 tys. osób.

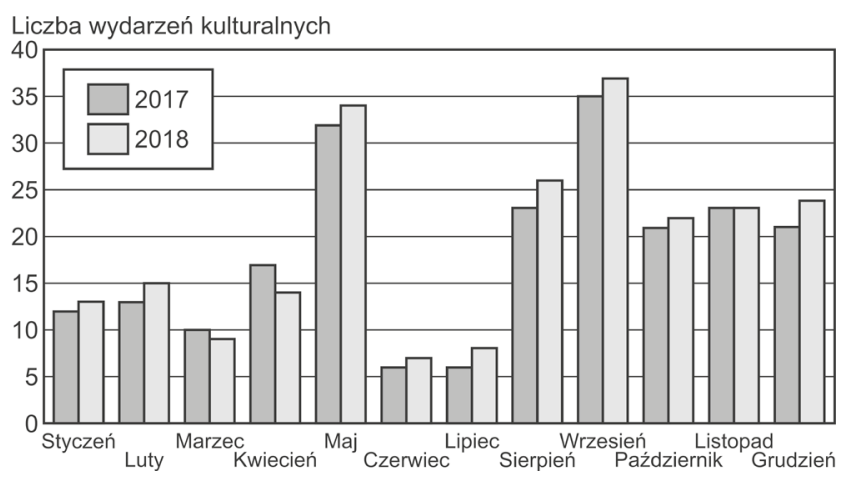

Rysunek 2. Wydarzenia kulturalne zorganizowane na terenie dawnej Kopalni Węgla Kamiennego "Guido" w 2017 i 2018 r.

Źródło: opracowanie własne na podstawie danych z Muzeum Górnictwa Węglowego w Zabrzu

Analizując rozkład wydarzeń kulturalnych, można zauważyć, iż kopalnia "Guido" stanowi swego rodzaju alternatywną przestrzeń w okresie, gdy „na powierzchni" organizacja tego typu wydarzeń staje się stosunkowo trudna ze względu na warunki atmosferyczne. 
Jednakże w związku z faktem, iż wszystkie wydarzenia organizowane są $w$ komorach górniczych, liczba uczestników poszczególnych imprez jest ograniczona (rys. 3). Popularność organizowanych wydarzeń kulturalnych w kopalni wynika z kilku czynników, do najważniejszych należą:

- nietypowa przestrzeń pod ziemią - komory w skale;

- niezwykle atrakcyjna i charakterystyczna akustyka udostępnianych sal - podziemnych komór skalnych;

- specyficzna architektura, charakteryzująca się surowością i stylem inustrialnym;

- „klimat” artystyczny związany z przejściem wąskimi korytarzami kopalni;

- zjazd starą windą (szola);

- połączenie elementów przemysłowych z nowoczesnymi rozwiązaniami technologicznymi.

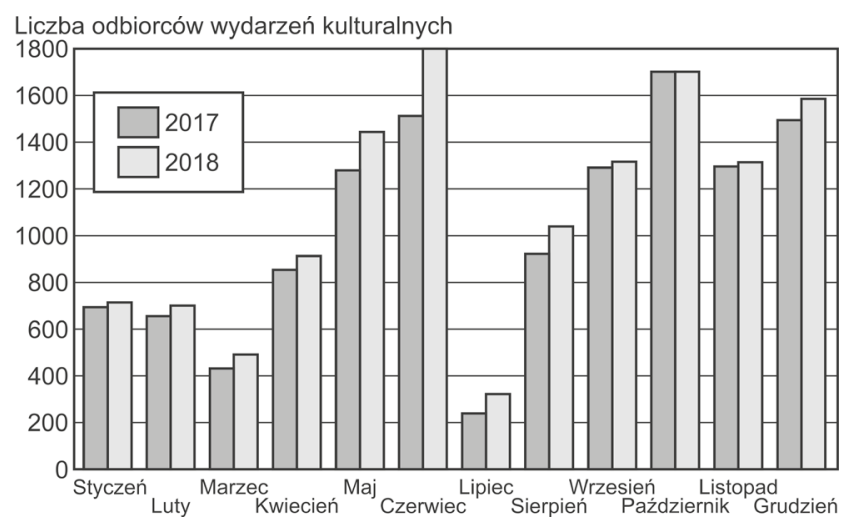

Rysunek 3. Uczestnicy wydarzeń kulturalnych zorganizowanych na terenie

dawnej Kopalni Węgla Kamiennego „Guido” w 2017 i 2018 r. Źródło: opracowanie własne na podstawie danych z Muzeum Górnictwa Węglowego w Zabrzu

Te czynniki sprawiaja, że wydarzenia organizowane pod ziemią mają niepowtarzalny klimat artystyczny, dzięki czemu stają się bardzo atrakcyjne. W całym regionie istnieje niewiele tego typu przestrzeni. Przykładem bardzo udanej rewitalizacji poprzemysłowej z podziemną salą koncertową na 100 osób jest Szyb Bończyk w Mysłowicach. Jednakże ma on całkowicie komercyjny charakter. Przestrzeń kopalni "Guido” w Zabrzu jest nie tylko obiektem udostępnionym dla zwiedzających, ale poprzez realizowane wydarzenia tematyczne wpisuje się w przestrzeń kreatywną ogólnie dostępną. Porównując ogólną liczbę uczestników wydarzeń kulturalnych w 2017 i 2018 r., zauważa się wzrost o $7,4 \%$. Analizując z kolei ich strukturę według poszczególnych miesięcy, wyraźnie widać dwa charakterystyczne okresy wzmożonej aktywności kulturalnej, wiosenny od kwietnia do czerwca oraz jesienny od września do grudnia. Jak już wspominano, może to wynikać z warunków pogodowych na powierzchni. Wiosną i jesienią aura często nie sprzyja organizowaniu koncertów i imprez plenerowych, ale w przypadku podziemi nie ma to większego znaczenia, ponieważ są to obszary zamknięte, ograniczone przestrzeniami podziemnymi o stałej temperaturze. Dlatego w okresie wiosennym i jesiennym jest to ciekawe miejsce spędzania wolnego czasu. Z kolei mniejsza aktywność letnia wynika ze słabszego zainteresowania podziemnymi imprezami wobec dużej oferty wydarzeń kulturalnych organizowanych na powierzchni przez różne miasta regionu oraz z powodu wakacji i wyjazdów mieszkańców regionu na urlopy. W tym czasie z kolei nasila się funkcja turystyczna, związana ze zwiedzaniem kopalni. Zatem można stwierdzić, że na atrakcyjność kopalni składają się trzy wzajemnie nakładające się działalności: turystyczna, kulturalna i edukacyjna. Każda z nich kierowana jest do innego odbiorcy, co przekłada się na znaczenie obiektu i na coraz większe oddziaływania zarówno kopalni „Guido”, jak i miasta.

W 2017 r. kopalnia „Guido” jako część Muzeum Górnictwa Węglowego otrzymała certyfikat Najlepszego Produktu Turystycznego przyznany przez Polską Organizację Turystyczną. Otrzymany tytuł ma duże znaczenie marketingowe $\mathrm{w}$ zakresie promowania miasta i budowania nowej marki, którą tworzy unikatowa podziemna przestrzeń kopalni „Guido”, coraz bardziej znana w kraju i Europie. Rozpoczęte działania mające na celu zbudowanie marki miasta są obecnie w początkowej fazie, a więc Zabrze jest jeszcze słabo rozpoznawane (Żemła, Szubert, 2019). Niemniej jednak mnogość działań rewitalizacyjnych obiektów poprzemysłowych $\mathrm{w}$ granicach administracyjnych miasta z założenia ma stworzyć jednorodny kompleks turystyczno-kulturalny, będący marką miasta promującego się hasłem „Miasto Turystyki Przemysłowej".

\section{DYSKUSJA}

Podziemne przestrzenie kopalni ukazują codzienność górników z przełomu XIX i XX w., która powoli staje się historią regionu śląskiego. Dlatego połączenie funkcji turystycznej w „Guido” (zwiedzanie) z funkcją kulturalna, umożliwia unaocznienie nie tylko dziedzictwa poprzemysłowego regionu górnośląskiego, ale jest przykładem kultury materialnej w nowej formie. Przestrzenie komór górniczych, w których organizowane są wszystkie wydarzenia kulturalne stanowią obszary wpisujące się w przemysł kreatywny. Nowa funkcja powstaje na podstawie "starego podłoża". Zabrze za pośrednictwem kopalni rozwija nietradycyjna, symboliczną funkcję miasta, która wchodzi w skład funkcji metropolitalnych (Zuzańska-Żyśko, 2016). Problematykę zagospodarowania obiektów poprzemysłowych w Zagłębiu Ruhry opisuje Zöpel (2011), ale także Chmielewska i Otto (2013), dokonując bardzo ciekawych porównań między Zagłębiem Ruhry i konurbacją górnośląską. 
Kulturalna działalność kopalni „Guido” jest odpowiedzią na rosnący popyt na tego typu wydarzenia ze strony mieszkańców regionu, ale także różnych instytucji i biznesu. Wielu gości zagranicznych, odwiedzających Górnośląsko-Zagłębiowską Metropolię i stolicę regionu - Katowice, korzysta z oferty kulturalno-turystycznej starych obiektów poprzemysłowych. W 2019 r. liczba uczestników wydarzeń kulturalnych w Katowicach przekroczyła po raz pierwszy milion osób (Rynek turystyki..., 2019). Zdaniem przewodników z kopalni „Guido' wielu zagranicznych gości to osoby ze świata biznesu lub goście zapraszani przez różne instytucje, a zatem osoby odbywające podróż służbową. Aleksandrowa, Rogowa i Sluka (2011) twierdza, że turyści biznesowi zostawiają trzy razy więcej pieniędzy niż indywidualni, odwiedzający obszar w celach poznawczych. W Katowicach, w świetle raportu (Rynek turystyki..., 2019), uczestnik konferencji nie korzystający z noclegu pozostawił w 2019 r. w mieście 178 zł. Zabrze jest położone zaledwie $20 \mathrm{~km}$ od Katowic, gdzie swoje siedziby ma ponad 70 filii i oddziałów firm o powiązaniach globalnych (Zuzańska-Żyśko, 2021). Ich przedstawiciele rozwijają różne sfery gospodarki, wspierają twórców, uczestniczą w wystawach i koncertach nie tylko w Katowicach, ale i w innych miastach Górnośląsko-Zagłębiowskiej Metropolii, w tym w Zabrzu.

Współczesne przemiany miast niejednokrotnie odbywają się w wyniku rewitalizacji terenów poprzemysłowych, przebiegają $\mathrm{w}$ podobny sposób $\mathrm{w}$ różnych krajach europejskich. Ponadto działania te wpisują się w europejski model „Kreatywna Europa”. Jednym z pierwszych obiektów, poddanym tego typu rewitalizacji w Europie, była belgijskiej kopalnia „Blegny-Mines" - uważa się, że jest to przykład najszybciej zrewitalizowanego obiektu poprzemysłowego. Przygotowania do przekształcenia rozpoczęto natychmiast po zaprzestaniu robót wydobywczych, efektem czego była szybko rosnąca liczba turystów. W 1980 r. nowy obiekt turystyczny odwiedziło 23 tys. osób, a w 1982 r. już ponad 40 tys. osób. Taki rezultat był możliwy jedynie dzięki zaawansowanym pracom nad uatrakcyjnieniem kopalni i przylegającego do niej terenu. Zbudowano Park Turystyczny „Blegny Mines” oraz centrum sportowo-rekreacyjne wraz z hotelem, wykorzystano infrastrukturę kolejową starych zakładów, przystosowano do zwiedzania podziemne wyrobiska (Jędrysiak, 2011). Kolejnym $\mathrm{z}$ bardziej znanych przykładów transformacji pogórniczych oraz poprzemysłowych obszarów miejskich na arenie europejskiej, który warto wskazać, jest kompleksowa i wielokierunkowa rewitalizacja zdegradowanych przestrzeni miejskich Dortmundu. Jak wskazuje Chmielewska (2012), wśród wielu działań rewitalizacyjnych miasta pojawił się projekt Phoenix \& Hord, w ramach którego odnowiono centralną część dzielnicy i przekształcono ją w nowoczesne centrum $\mathrm{z}$ terenami usługowymi i kulturalno-rozrywkowymi.
Podobieństwo przemian z analizowanym obiektem w Zabrzu, ze względu na historię poprzemysłowa, widoczne jest również na obszarze Vitkovic i Poruby w czeskiej Ostrawie. W ramach rewitalizacji powstały przestrzenie o różnych funkcjach turystycznych, m.in. muzealne. Do najważniejszych zaliczyć należy ogromny, cylindryczny budynek, powstały z dawnego stalowego zbiornika na gaz, który współcześnie pełni funkcję sal konferencyjnych oraz kawiarni. Jest to doskonały przykład zaaranżowania powierzchni poprzemysłowej na cele rozrywkowe. Warto wspomnieć również o Łodzi, gdzie w dawnych fabrykach włókienniczych niektóre przestrzenie zostały zaadaptowane na potrzeby związane z kulturą. Ten nowy sposób zagospodarowania uzupełnia inne funkcje przekształcenia zabytkowych murów na potrzeby handlu czy biur (Sokołowicz, Zasina, 2016). W Górnośląsko-Zagłębiowskiej Metropolii przeprowadzono wiele udanych projektów rewitalizacyjnych na terenach poprzemysłowych i pokopalnianych. Największym z nich jest Strefa Kultury w Katowicach na terenie zamkniętej w 1999 r. Kopalni Węgla Kamiennego „Katowice”. Powstały tam trzy różne instytucje: Muzeum Śląskie, Narodowa Orkiestra Symfoniczna Polskiego Radia oraz Międzynarodowe Centrum Kongresowe. Podziemne tereny kopalni zostały całkowicie przekształcone na bardzo nowoczesne przestrzenie metropolitalne o charakterze muzealnym, częściowo konferencyjnym i w większości są obecnie częścią Muzeum Śląskiego.

Opisane obiekty, które w przeszłości pełniły funkcję produkcyjna, zmieniono $\mathrm{w}$ przestrzeń kreatywną dla nowych odbiorców, już nie tylko dla górników, hutników czy pracowników przemysłu, ale też dla osób i turystów poszukujących wiedzy, dla klasy kreatywnej szukającej inspiracji, ludzi oczekujących wrażeń, kontaktu z kultura, rekreacją i rozrywką. Obiekty poprzemysłowe, podlegając sukcesji funkcji, zyskały "drugie życie" i pełnią już zupełnie inne funkcje - nie produkcyjne lecz związane z tzw. usługami wysokimi. Tworzenie nowych produktów turystycznych na bazie postindustrializmu jest odpowiedzią na potrzeby ludzi identyfikujących się z europejskim dziedzictwem przemysłowym.

\section{PODSUMOWANIE}

Współcześnie rozwój miast ma na celu podniesienie ich atrakcyjności. Coraz częściej w miastach, w których w przeszłości dominował przemysł, wykształcają się nowe funkcje, w tym o profilu kulturowym. Dzięki wiedzy, kreatywności i nowoczesnym technologiom tworzone są nowe, unikatowe przestrzenie kultury w starych obiektach poprzemysłowych. Kopalnia "Guido" w Zabrzu jest dobrym przykładem wykreowania nowej 
funkcji turystycznej na podstawie starej funkcji górniczej. Udostępniona dla ruchu turystycznego przestrzeń systematycznie umacnia pozycję na rynku nie tylko turystycznym, ale i kulturalnym. Z jednej strony w kopalni pokazuje się turyście dziedzictwo związane z działalności przemysłową i górnicza, z drugiej używa się nietypowej przestrzeń pod ziemią do tworzenia kultury w rzadko spotykanej scenerii. Wykorzystując komory górnicze do organizacji wydarzeń kulturalnych, w Zabrzu stworzono nowy i rzadki produkt turystyki poprzemysłowej. Usługi wykreowane $\mathrm{w}$ mieście na bazie dziedzictwa kulturowego lokują Zabrze w grupie ośrodków rozwijających nowe funkcje symboliczne, będące bardzo specyficznym typem funkcji metropolitalnych. Dają one miastu nadwyżkę znaczeniową w gronie innych ośrodków Górnośląsko-Zagłębiowskiej Metropolii. Dzięki sukcesji funkcji kopalni „Guido" Zabrze rozpoczęło budowanie nowej marki miasta, która w przyszłości może być rozpoznawalna nie tylko w regionie, ale i w kraju.

\section{BIBLIOGRAFIA}

Aleksandrowa, A., Rogowa, S., Sluka, N. (2011). Miasta globalne w systemie ośrodków turystyki międzynarodowej. W: B. Włodarczyk (red.), Turystyka. Księga jubileuszowa w 70 rocznicę urodzin Profesora Stanisława Liszewskiego (s. 136-151). Łódź: Wydawnictwo Uniwersytetu Łódzkiego.

Borowiecki, R. (2004). Perspektywy rozwoju sektora kultury w Polsce. Kraków: Oficyna Ekonomiczna.

Chmielewska, M. (2009). Osiedla i kolonie robotnicze w Katowicach - identyfikacja, rozmieszczenie i stan zachowania. Acta Geographica Silesiana, 6, 9-14.

Chmielewska, M. (2010). Rewaloryzacja przestrzeni przemysłowej w miastach konurbacji katowickiej. W: M. Madurowicz (red.), Wartościowanie wspótczesnej przestrzeni miejskiej (s. 165-173). Warszawa: Wydział Geografii i Studiów Regionalnych Uniwersytetu Warszawskiego i Urząd m.st. Warszawy.

Chmielewska, M. (2012). Revitalization of former industrial space versus sustainable development - the 'Phoenix Dortmund' project (Ruhr area, Germany). W: I.I. Pirožnik (i in.), Geographical sciences in realization of sustainable development strategy in globalizing world (to the 100 th anniversary of Professor N.T. Romanovskij) (s. 76-78). Mińsk: Izdatel'skij Centr BGU.

Chmielewska, M., Otto, M. (2013). Wpływ rewitalizacji na ewolucję przestrzeni miejskiej na terenach dawnych hut żelaza i stali w Zagłębiu Ruhry (Niemcy). Badania środowiskowe i społeczno-ekonomiczne, 1 (1), 31-37.

Głowacki, J. (2017). Przemysły kreatywne i ich wpływ na gospodarkę. W: J. Hausner, A. Karwińska, J. Purchala (red.), Kultura a rozwój (s. 435-454). Kraków: Narodowe Centrum Kultury.

Gorzelak, G. (2000). Zewnętrzna interwencja jako czynnik rozwoju lokalnego (na przykładzie programu inicjatyw lokalnych). Studia Regionalne i Lokalne, 3 (3), 99-120.

Hnatyszyn, P. (1999). Zabrze na starych mapach i pocztówkach. Radzionków: P.P.H.U. „ROCOCO” J. Krawczyk.

Hnatyszyn, P. (2002). Zabrze przed 100 laty. Nasze Zabrze Samorzadowe, 12/2002, 20.
Jędrysiak, T. (2011). Turystyka kulturowa w obiektach poprzemysłowych - zagadnienia ogólne. Turystyka kulturowa, 6, 17-35.

Jokela, S. (2018). Rozwój marki miasta Helsinek. Helsinki Quarterly, 2/2018. Pobrane z: https://www.kvartti.fi/en/articles/development-helsinkis-city-brand (5.07.2019).

Karwińska, A. (2013). Kultura a rozwój. Warszawa: Narodowe Centrum Kultury.

Koman, W. (2015). Zabrze poligonem geograficznych zajęć terenowych. W: R. Machowski, M.A. Rzętała (red.), Z badań nad wptywem antropopresji na środowisko (s. 97-104). Sosnowiec: Studenckie Koło Naukowe Geografów Uniwersytetu Śląskiego, Wydział Nauk o Ziemi Uniwersytetu Śląskiego.

Kopalnia „Guido” (2020). Oferta sponsorska. Pobrane z: https:// kopalniaguido.pl/index.php/?option=com_content\&view=ar ticle\&id=449\&Itemid=552 (5.07.2019).

Kultura (1971). Stownik wyrazów obcych i wyrazów obcojęzycznych. Warszawa: Wiedza Powszechna, s. 611.

Lamparska, M. (2017). Osiedla patronackie w kulturowej przestrzeni Europy. Acta Geographica Silesiana, 11/2 (26), 51-61.

Lisowski, A. (2003). Koncepcje przestrzeni w geografii człowie$k a$. Warszawa: Wydział Geografii i Studiów Regionalnych Uniwersytetu Warszawskiego.

Mroki Kopalni - trasa tymczasowo wstrzymana (2020). Pobrane z: https://kopalniaguido.pl/index.php/mroki-kopalni-guido (5.07.2019).

Myga-Piątek, U. (2016). Krajobraz jako autentyk, makieta, hybryda. Rozważania o roli krajobrazu we współczesnej turystyce. Turystyka Kulturowa, 1, 47-63.

Namyślak, B. (2013). Miasto kreatywne w ujęciu teoretycznym. Studia Ekonomiczne i Regionalne. T. VI (2). Biała Podlaska: Państwowa Szkoła Wyższa im. Papieża Jana Pawła II w Białej Podlaskiej.

Przecławski, K. (1997). Turystyka a kultura na przełomie XX i XXI wie$k u$. Warszawa: Polskie Stowarzyszenie Turystyki.

von Rohrscheidt, A.M. (2010). Turystyka kulturowa. Fenomen, potencjat, perspektywy. Poznań: Wydawnictwo KulTour.pl.

Runge, J. (2015). Regionalne i lokalne konsekwencje współczesnych przemian demograficznych Polski - elementy metodologii badań. Przykład województwa śląskiego. Studia Ekonomiczne. Zeszyty Naukowe Uniwersytetu Ekonomicznego w Katowicach, 223, 279-289.

Runge, J. (2016). Przestrzeń publiczna złożonych układów osadniczych. W: K. Gasidło, T. Bradecki (red.), Wielkie inwestycje publiczne w miastach aglomeracji. T. 1 (s. 164-172). Gliwice: Wydawnictwo Politechniki Gliwickiej.

Rynek turystyki biznesowej w Katowicach w 2019 roku (2019). Pobrane z: https://www.katowice.eu/biznes/convention-bureau/turystyka-biznesowa (5.07.2019).

Scott, A.J. (1997). The Cultural economy of cities. International Journal of Urban and Regional Research, 21 (2), 323-339. https:// doi.org/10.1111/1468-2427.00075

Sheng, L., Wang, T.L.J. (2017). Tourism and externalities in an urban context: Theoretical model and empirical evidence. Cities, 70 (10), 40-45. https://doi.org/10.1016/j.cities.2017.06.012

Sokołowicz, M., Zasina, J. (2016). Sektor kultury jako czynnik transformacji miasta przemysłowego w kierunku miasta kreatywnego i inteligentnego? Przykład Łodzi. Acta Universitatis Lodziensis. Folia Oeconomica, 4 (324), 5-19. https:// doi.org/10.18778/0208-6018.324.01

Stasiak, A. (2019). Przestrzeń turystyczna jako przestrzeń doświadczeń. Prace i Studia Geograficzne, 64 (1), 61-87.

Stawasz, D. (2017). Ekonomia instytucjonalna wobec problemu rozwoju miasta. Biuletyn PAN KPZK, 265, 7-21.

Strycharz, J. (2013). Organizacje sektora kultury a rozwój. W: J. Hausner, A. Karwińska, J. Purchla (red.), Kultura a rozwój (s. 175-192). Warszawa: Narodowe Centrum Kultury. 
Szafranek, E. (2019). Terytorializacja polityki rozwoju. Wdrażanie Zintegrowanych Inwestycji Terytorialnych w obszarach funkcjonalnych miast $w$ Polsce. Opole: Uniwersytet Opolski.

Szychta - tymczasowo wstrzyma (2020). Pobrane z: https://kopalniaguido.pl/index.php/guido-szychta (5.07.2019).

Toffler, A. (1986). Trzecia fala. Warszawa: Państwowy Instytut Wydawniczy.

Wilkin, J. (2016a). Instytucjonalne i kulturowe podstawy gospodarowania: humanistyczna perspektywa ekonomii. Warszawa: Scholar.

Wilkin, J. (2016b). Kultura a gospodarka - niedocenianie wspótzależności. Referat konferencyjny "Ekonomiczna pozycja Europy w świecie i możliwości jej trwałego rozwoju". Warszawa: PAN, Komitet Prognoz „Polska 2000 plus”.

Zöpel, Ch. (2011). Zagłębie Ruhry i Górny Śląsk w sieci metropolii europejskich. Aglomeracje przemysłowe jako metropolitalne obszary miejskie. Gliwice-Opole: Dom współpracy Polsko-Niemieckiej, Fundacja im. Friedricha Eberta.
Zuzańska-Żyśko, E. (2016). Procesy metropolizacji. Teoria i praktyka. Warszawa: Wydawnictwo Naukowe PWN.

Zuzańska-Żyśko, E. (2021). Role of advanced producer services shaping globalization processes in a post-industrial region: The case of the górnoślasko-zagłębiowska metropolis. Journal Article Sustainability (Switzerland), 13 (1), 1-19. https:// doi.org/10.3390/su13010211

Żemła, M., Szubert, M. (2019). Wizerunek miast konurbacji górnośląskiej - wyzwanie przełamywania stereotypów. Annales Universitatis Paedagogicae Cracoviensis Studia Geographica, 13, 57-77. https://doi.org/10.24917/20845456.13.5

Artykuł wpłyną:

12 kwietnia 2020

Zaakceptowano do druku:

5 grudnia 2020 